\title{
Review
}

\section{Recent advances in (patho)physiology of astroglia}

\author{
Alexei VERKHRATSKY ${ }^{1,2, *}$, Vladimir PARPURA ${ }^{3}$ \\ ${ }^{1}$ Faculty of Life Sciences, The University of Manchester, Manchester, UK; ${ }^{2} I K E R B A S Q U E$, Basque Foundation for Science, 48011 , \\ Bilbao, Spain; ${ }^{3}$ Department of Neurobiology, Center for Glial Biology in Medicine, Civitan International Research Center, Atomic Force \\ Microscopy \& Nanotechnology Laboratories, and Evelyn F McKnight Brain Institute, University of Alabama, Birmingham, USA
}

Our view of astrocytes in the operation of the brain is changing dramatically over the last 3 decades. Astroglial calcium excitability controls the release of gliotransmitters, which can occur at the tripartite synapse. Astrocytes not only modulate synaptic transmission by releasing and taking up transmitters, but also receiving neuronal signals that act upon astrocytic plasma membrane receptors. This process represents the bidirectional neurone-glia communication. Additionally, astrocytes play role in the regulation of blood flow as well as ion and water homeostasis. Many of the brain dysfunctions are primary astropathies, including hepatic encephalopathy and Alexander disease, while other brain malfunctions, such as epilepsy and Alzheimer disease, may have substantial astrocytic contribution. Thus, these star-shaped cells by their roles in (patho)physiology of the brain seem to live up to the expectation one can have from their given name - astrocyte.

Keywords: neuroglia; astrocyte; gliotransmission; neuropathology; neurodegeneration

Acta Pharmacologica Sinica (2010) 31: 1044-1054; doi: 10.1038/aps.2010.108; published online 9 Aug 2010

\section{History of glial research}

At the dawn of neuroscience all neural cells were equal. Indeed early neuroanatomists were describing both neuronal and glial elements of the nervous system without assigning them special priorities. The first descriptions of neurones were made by Christian Gottfried EHRENBERG (1836), by Johann Evangelista PURKINJE (1835-1837), and by Gustav Gabriel VALENTIN (1836). At the very same time Robert REMAK discovered glial sheath surrounding axons, and in 1850-ies Heinrich MÜLLER, Max SCHULZE and Karl BERGMANN made first detailed investigations of glial cells in retina and in cerebellum. The concept of glia as a connective tissue component of the CNS was introduced by Rudolf VIRCHOW, who also introduced the idea of supportive role of neuroglia, which is the "substance... which lies between the proper nervous parts, holds them together and gives the whole its form in a greater or less degree" ${ }^{[1]}$. Very soon after Virchow however, the cellular nature of glia was firmly established and many types of glial cells were revealed and minutely described (for more detailed account on the history of glial research see ${ }^{[2,3]}$ ). Initially all glial cells in the CNS were classified as "spider" or "stellate" cells. The term "astrocyte" was introduced in 1891

\footnotetext{
* To whom correspondence should be addressed.

E-mail alex.verkhratsky@manchester.ac.uk

Received 2010-06-03 Accepted 2010-07-01
}

by Michael von LENHOSSEK ${ }^{[4]}$; very soon after Rudolf Albert von KÖLLIKER and William Lloyd ANDRIEZEN ${ }^{[5,6]}$ further classified astroglia into protoplasmic and fibrous astrocytes located in the grey and in the white matter respectively. The second and third neuroglial elements, represented by oligodendrocytes and microglia were identified by Pio del RÍOHORTEGA in 1920-ies ${ }^{[7-9]}$.

By the beginning of 20-ies century the preponderance of glia in the human CNS was universally accepted; similarly the great morphological variety of astrocytes was widely documented $^{[10]}$. Numerous hypotheses were also proposed to understand the function of neuroglia. Some of these hypotheses regarded glia as completely passive insulators (Pedro Ramon Y CAJAL), some highlighted the role of neuroglia in metabolic support of nerve elements (Camillo GOLGI), or proposed that that these cells may release substances into the blood, acting like an endocrine gland (Jean NAGEOTTE), and at least one hypothesis regarded neuroglia as a major regulator of information processing in the brain (Carl Ludwig SCHLEICH). All this hypothesising however came to an abrupt end with the final victory of the neuronal doctrine (that occurred at the beginning of 20-ies century) that regarded synaptically connected neuronal networks as a sole substrate for brain functional activity, leaving neuroglia in the position of passive supporters. As a result, the glial research remained dormant for almost three quarters of a century. In the last 3 
decades however, this changed dramatically and many exciting discoveries elevated glia to a substantially more dignified position. In this essay we attempt to provide a concise account of major advances in the physiology and pathophysiology of astroglia.

\section{Physiology of astroglia}

The astrocytes, which are the most numerous cells in the human brain, have many functions (Table 1). First and foremost, astrocytes represent the main cellular element of homeostatic system, which is responsible for all aspects of metabolic support, nutrition, control of ion and neurotransmitter environment, regulation of brain-blood barrier and defence of the central nervous system ${ }^{[11]}$. In addition, astrocytes express a multitude of signalling cascades, are endowed with trans-cellular communication routes represented by gap junctions and are able to release a wide array of gliotransmitters via several regulated pathways. This complex signalling machinery may involve astroglia in a variety of information processing routines existing in the CNS and make astrocytes indispensable elements in shaping higher cognitive functions of the brain.

\section{Astrocytes shape the grey matter}

Astroglia define the micro-architecture of the grey matter by

Table 1. Functions of astroglial cells (modified from ${ }^{[11]}$ ).

Astroglial functions

Developmental Regulation of neuro- and gliogenesis - astroglia are stem elements of the CNS

Neuronal path finding

Regulation of synaptogenesis

Structural

Astroglia divide the grey matter into independent territories and form neuro-vascular units

Astrocytes form anatomically segregated syncytia and integrate other neural cells into this syncytium

Formation of the glial-vascular interface and regulation of blood-brain barrier

Metabolic Regulation of cerebral microcirculation Providing energy substrates for neurones through glucose-lactate shuttle

Homeostatic

Regulation of extracellular ion concentrations; in particular sequestration and redistribution of $\mathrm{K}^{+}$ following fluctuations associated with neuronal activity Regulation of extracellular $\mathrm{pH}$

Homeostasis of neurotransmitters and specifically glutamate

Brain water homeostasis

Signalling dividing the latter into relatively independent structural units. The protoplasmic astrocytes occupy defined territories and create the micro-anatomical domains within the limits of the arborisation of their processes ${ }^{[12-16]}$ (Figure 1). Astrocytes have extensive morphological interactions with neurones within their individual domains. For instance, one astrocyte may contact 4 to 8 neurones and surround $\sim 300$ to 600 neuronal dendrites ${ }^{[17]}$ in the cortex of adult mice. In the hippocampus astrocytes are prolifically in contact with synapses. In adult rats, one astrocyte is estimated to contact $\sim 140000$ synapses in the CA1 area ${ }^{[13]}$. These individual astroglial domains are further integrated into astroglial syncytia through gap junctions, mainly localised on the peripheral processes of astroglial cells. These astroglial syncytia form the main pathway for inter-glial communications ${ }^{[18]}$. The astroglial syncytia can also be anatomically segregated because they are formed within defined anatomical structures, for example in individual barrels of the somatosensory cortex ${ }^{[19]}$. It should be noted, however, that the extent of gap-junctional connectivity between glial cells greatly varies between different regions of the brain, or even within a region, $e g$, within hippocampus ${ }^{[20]}$.

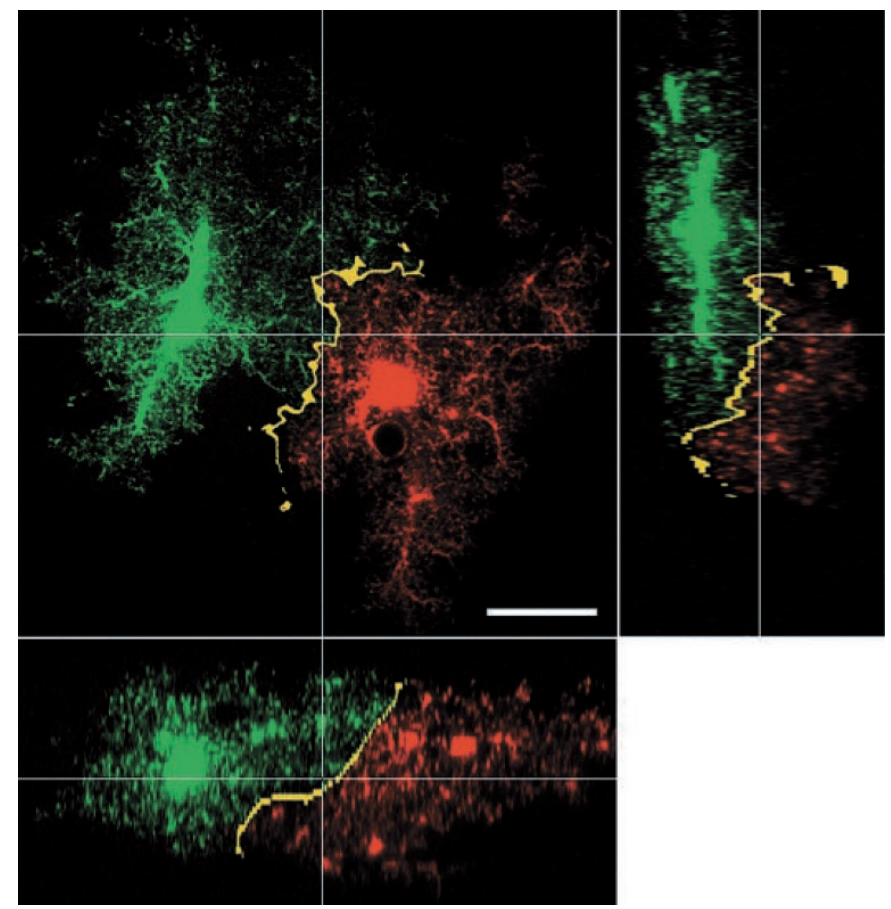

Figure 1. The protoplasmic astrocytes occupy defined territories within the CNS. Two adjacent astrocytes create their micro-anatomical domains (green and red). Only at the cells' peripheries do their processes overlap (yellow). Images represent $x-y$ (large), $x-z$ (bottom), and $y-z$ (right) projections. Scale bar, $20 \mu \mathrm{m}$. Reprinted, with permission from ${ }^{[13]}$ and the Journal of Neuroscience (Copyright 2002 by the Society for Neuroscience).

\section{Astrocytes form communication "channels" with nearby neurones}

Astrocytes can listen and talk to neurones via transmitter release $^{[21]}$. This is because of the intimate structural relation- 
ship between these neural cells referred to as the tripartite synapse, whereby neuronal pre- and post-synaptic elements are enwrapped by glial cell processes (Figure 2A). It is at the tripartite synapse where neurotransmitter released via synaptic transmission signals to adjacent glial cells and vice versa, astrocytic processes at the tripartite synapses possess gliotransmitter (often the same chemical as neurotransmitter, eg, glutamate) vesicles (Figure $2 \mathrm{~B}$ ) and by releasing it can modulate synaptic transmission and plasticity ${ }^{[22]}$. Tripartite synapses are ubiquitously present throughout CNS. In the stratum radiatum of hippocampal CA1 region, $57 \%$ of the synapses formed between Schaffer collaterals and CA1 pyramidal neurones are in contact with astrocytes ${ }^{[23]}$. However, the degree of synaptic coverage by glia is a dynamic process, as best described in the magnocellular hypothalamo-neurohypophysial system ${ }^{[24]}$.

Neurone-glia signalling can also occur through direct synapse-like connections synaptoids, ectopic sites at pre-synaptic terminals or even bona fide synaptic contacts (Figure 2C-2E). Thus, neuroglia are capable of responding to neuronal activity

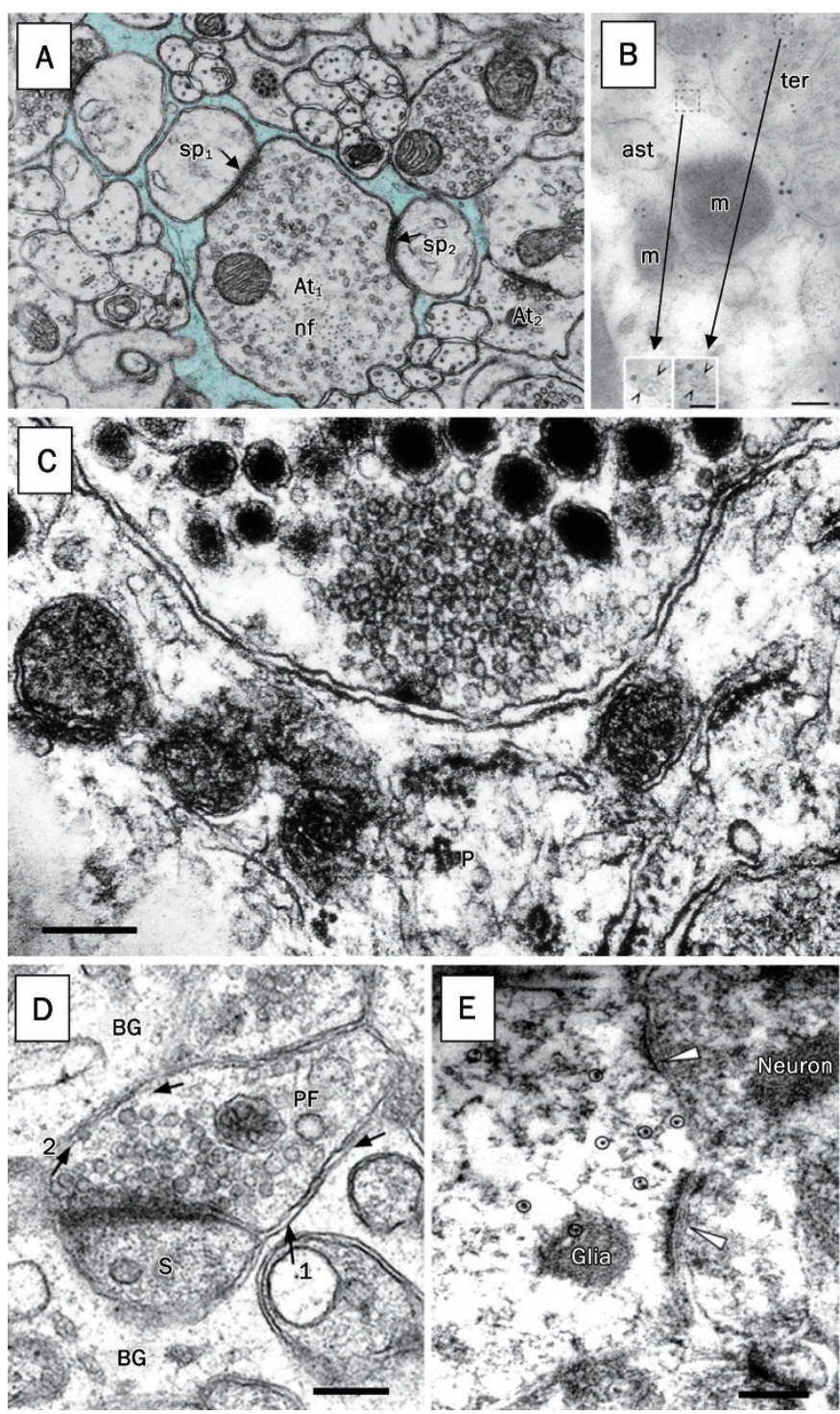

at various levels/modes of neurotransmitter release including single action potential driven release as well as asynchronous quantal release.

Synaptoid contacts occur where axonal projections end on glial cells without notable presence of post-synaptic differentiation (PSD) on glia (Figure 2C). Such direct synapse-like contacts have been described in pituicytes, specialized astrocytic cells, where stimulation of neuronal terminals caused $\gamma$-amino butyric acid (GABA) and dopamine mediated depolarizations of pituicytes in situ ${ }^{[25]}$. Synaptoids also exist on septohippocampal astrocytes formed by inputs from norepinephrine terminals ${ }^{[26]}$

Bergmann glia, an astroglial cell found in the cerebellum, can receive inputs from climbing and parallel fibres in situ ${ }^{[27]}$. Here, exocytosis of glutamate occurring at active zones excites Purkinje cells, while ectopic exocytotic glutamate release is used for signalling to Bergmann glia. Naturally, ectopic release sites are defined as release sites outside of the active zones of the presynaptic terminals (Figure 2D).
Figure 2. Types of contacts between neuronal terminals and astroglia. (A) An electron micrograph demonstrates the tripartite synapse. The cytoplasm of an astrocyte (blue) contacts axon terminals (At) forming synapses onto spines. Two synapses ( $\mathrm{sp}_{1}$ and $\mathrm{sp}_{2}$; arrows) are enwrapped by the astrocyte, while two other synapses (at $A t_{1}$ and $\left.A t_{2}\right)$ are in close apposition to the astrocyte; nf, neurofilaments. (B) Glutamatergic vesicles at the putative tripartite synapse. Immuno-electron micrograph of vesicular glutamate transporter 1 (VGLUT1) (small gold particles) in astrocytic process (ast) identified by GLT/GLAST labelling (large gold particles). VGLUT1 positive vesicles (insets, open arrowheads) in an astrocyte and in the adjacent neuronal terminal (ter) have similar appearances; $\mathrm{m}$, mitochondria. (C) Neurosecretory axon containing both dense core and clear secretroy vesicles making a synaptoid contact with a pituitary astrocyte $(P)$. The post-synaptic membrane differentiations are completely absent on the astrocyte apposing the presynaptic terminal. (D) Parallel fibre terminal (PF) is making a synapse on a dendritic spine (S) of a Purkinje neurone. Close appositions of Bergmann glia (BG) and PF membranes contain extracellular electron dense material (arrows, 1 and 2). Synaptic vesicles are morphologically docked to the presynaptic differentiations and close to the presynaptic membrane facing the BG. (E) Synaptic structures with typical neuronal synaptic terminals containing vesicles contact (arrowheads) the EGFP/GFAP-positive glial cells labelled using indirect immunocytochemistry with anti-GFP and secondary antibody conjugated to gold particles (circles). Note postsynaptic densities in glial elements. Scale bars, $100 \mathrm{~nm}$ in B (50 nm inset), $330 \mathrm{~nm}$ in C, $100 \mathrm{~nm}$ in D, and $250 \mathrm{~nm}$ in E. Micrograph in $A$ is modified from ${ }^{[111]}$ and reprinted from ${ }^{[24]}$, with permission from American Physiological Society. Micrograph in $B$ is adapted by permission from Macmillan Publishers Ltd: Nature Neuroscience ${ }^{[112]}$, copyright 2004. Micrograph in C courtesy of the late Dr Glenn I. Hatton, University of California Riverside. $D$ is reprinted from ${ }^{[27]}$, with permission from the Journal of Neuroscience (Copyright 2005 by the Society for Neuroscience). E is reprinted from ${ }^{[29]}$, with permission from the Company of Biologists Ltd. 
Direct glutamatergic and GABAergic synapses on glial cells were observed in the hippocampus. Such synapses are formed on glial cells expressing the proteoglycan NG2, and hence regarded as oligodendrocyte precursor cells (OPCs) ${ }^{[28]}$ or on a subset of cells displaying the astrocytic marker glialfibillary acidic protein (GFAP) termed GluR cells ${ }^{[29]}$. However, GluRs not only co-express common astrocytic markers S-100 $\beta$ and GFAP, but also the proteoglycan NG2, and have transcripts for mainly neuronal excitatory amino acid carrier 1. Consequently, they do not match a definition of the "classical" astrocyte. Nonetheless, at the ultrastructural level, neuronal inputs onto GluR astroglial cells show all the morphological characteristics of chemical synapses, having the typical features of the neuronal pre-synaptic terminal with apposing PSDs in postsynaptic glial element (Figure 2E).

The existence of multiple structures mediating the transfer of information from neurones to glial cells using spillover, synaptoid, ectopic sites, and direct chemical synapses suggest a high level of complexity and specificity in neurone-glia signalling.

\section{Astrocytes express "excitable" molecules}

The seminal discovery of ionotropic glutamate receptors in neuroglia was made in 1984, when it was found that externally applied excitatory amino acids (glutamate and aspartate) depolarised astrocytes and oligodendrocytes maintained in cell culture ${ }^{[30,31]}$. In the next decade the wide variety of both neurotransmitter receptors and ion channels was discovered and characterised in astrocytes; in fact the astroglia was found to express virtually every type of ion channel and/or receptor present in the nervous system ${ }^{[32,33]}$.

The receptors expression in glial cells in vivo is tightly controlled and astrocytes from different brain regions have very distinct complement of receptors. Often the receptor patterns expressed by astroglia match the receptors present in their immediate neuronal neighbourhood. For example Bergman glial cells and their intimate associates, Purkinje neurones, express receptors for adrenalin, histamine, glutamate, GABA and adenosine $5^{\prime}$-triphosphate (ATP), these receptors being congruent to the neurotransmitters released in this anatomical region ${ }^{[34-36]}$.

The most widespread receptors in astroglia are represented by glutamate receptors and purinoceptors. Majority of astroglial cells throughout the brain express metabotropic glutamate receptors that initiate $\mathrm{Ca}^{2+}$ signalling through phospholypase $\mathrm{C} / \mathrm{InsP}_{3}$-mediated $\mathrm{Ca}^{2+}$ release from the $\mathrm{ER}^{[36]}$. The main astroglial ionotropic glutamate receptors is of AMPA-type, which often is expressed in $\mathrm{Ca}^{2+}$-permeable form ${ }^{[32,33]}$. Cortical astrocytes express NMDA receptors of specific "glial" variety characterised by an absence of $\mathrm{Mg}^{2+}$ block ${ }^{[37,38]}$. Through activation of their glutamatergic receptors astrocytes are able to "sense" synaptic transmission ${ }^{[36]}$.

The purinoceptors and purinergic signalling system is of specific importance for neuroglia, because virtually every type of glial cell does have sensitivity to ATP or adenosine ${ }^{[39]}$. The reason probably lies in the ancient evolutionary roots of the purinergic signalling system that from the very beginning of evolution has been employed as a main "warning" or "danger" signaller ${ }^{[40,41]}$; the neuroglia being the defender of the nervous system inherited this sensitivity to purines. The astroglial cells express both P1 (adenosine) and P2 (ATP and other nucleotides) receptors (Table 2). The metabotropic P2Y receptors are particularly abundant in astrocytes; the $\mathrm{P}_{2} \mathrm{Y}_{1}$, $\mathrm{P} \mathrm{Y}_{2}$, and $\mathrm{P} 2 \mathrm{Y}_{6}$ subtypes being largely expressed ${ }^{[39]}$. Expression of ionotropic purinoceptors is much less explored; so far a specific expression of $\mathrm{P} 2 \mathrm{X}_{1 / 5}$ heteromeric receptors was demonstrated in cortical astroglia ${ }^{[42]}$. The $\mathrm{P} 2 \mathrm{X}_{1 / 5}$ receptors are distinguished by extraordinary high sensitivity to ATP $\left(\mathrm{EC}_{50}\right.$ about $50 \mathrm{nmol} / \mathrm{L}$ ) and absence of desensitisation. These peculiarities make the perfect sensor to monitor the ambient ATP fluctuation in the brain interstitium. There are some indications of astroglial expression of $\mathrm{P} 2 \mathrm{X}_{7}$ receptors $^{[43,44]}$, although these latter are probably relevant for pathological processes as various insults to the brain trigger significant up-regulation of $\mathrm{P} \mathrm{X}_{7}$ expression in astrocytes ${ }^{[39]}$.

Table 2. Mammalian purine/pyrimidine receptors expression in the brain/ astrocytes and their agonists.

\begin{tabular}{llcc}
\hline \multicolumn{1}{c}{ Receptor } & \multicolumn{1}{c}{ Agonist(s) } & Brain & Astrocyte \\
\hline$(\mathrm{P} 1) \mathrm{A}_{1,2 \mathrm{~A}, 2 \mathrm{~B}, 3}$ & Adenosine & + & + \\
$\mathrm{P} 2 \mathrm{X}_{1-7}$ & ATP $\left(\text { except } \mathrm{P}^{2} \mathrm{X}_{6}\right)^{*}$ & + & + \\
$\mathrm{P} 2 \mathrm{Y}_{1}$ & ADP $>$ ATP & + & + \\
$\mathrm{P} 2 \mathrm{Y}_{2}$ & UTP=ATP & + & + \\
$\mathrm{P} 2 \mathrm{Y}_{4}$ & UTP $\geq$ ATP & + & + \\
$\mathrm{P} 2 \mathrm{Y}_{6}$ & UDP> UTP $>$ ATP & + & + \\
$\mathrm{P} 2 \mathrm{Y}_{11}$ & ATP & + & \\
$\mathrm{P} 2 \mathrm{Y}_{12}$ & ADP $>$ ATP & + & + \\
$\mathrm{P} 2 \mathrm{Y}_{13}$ & ADP $>$ ATP & + & \\
$\mathrm{P} 2 \mathrm{Y}_{14}$ & UDP-glucose & + & + \\
\hline
\end{tabular}

Receptor families: P1, adenosine; P2 for ATP and ADP, P2X are ionotropic, $\mathrm{P} 2 \mathrm{Y}$ are metabotropic. ${ }^{*} \mathrm{P} 2 \mathrm{X}_{6}$ does not form a homodimer. $\mathrm{P} 2 \mathrm{Y}_{5}, \mathrm{P} 2 \mathrm{Y}_{7}$, $\mathrm{P} 2 \mathrm{Y}_{9}, \mathrm{P}_{2} \mathrm{Y}_{10}$ do not show responses to nucleotides. $\mathrm{P} 2 \mathrm{Y}_{3}$ is an avian ortholog of $P 2 Y_{6}$. $P 2 Y_{8}$ from Xenopus laevis shows high homology to mammalian $\mathrm{P}_{2} \mathrm{Y}_{2}$ and $\mathrm{P} 2 \mathrm{Y}_{4}$.

\section{Calcium excitability of astroglia}

Despite the widespread expression of excitable molecules in astroglial plasma membrane, these cells remain electrically non-excitable because high density of $\mathrm{K}^{+}$channels precludes regenerative depolarisation and action potential generation. Nonetheless astrocytes employ intracellular endomembrane as an excitable media (Figure 3). The endomembrane form the endoplasmic reticulum (ER) that provides for many levels of intracellular signalling and integration, being in particular the main dynamic intracellular $\mathrm{Ca}^{2+}$ store $^{[45,46]}$. The ER is able to accumulate large amounts of $\mathrm{Ca}^{2+}$ via the activity of sarco(endo)plasmic reticulum $\mathrm{Ca}^{2+}$ ATPases, SERCAs; the intra-ER free $\mathrm{Ca}^{2+}$ concentration is comparable with extracellular free $\mathrm{Ca}^{2+}$, being in the range of $400-800 \mu \mathrm{mol} / \mathrm{L}^{[47,48]}$. The 


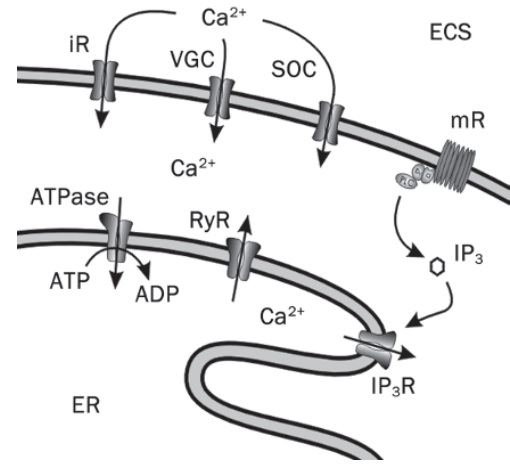

Figure 3. $\mathrm{Ca}^{2+}$ excitability of astrocytes. A drawing of sources of $\mathrm{Ca}^{2+}$ for cytosolic $\mathrm{Ca}^{2+}$ increase. Cytosolic $\mathrm{Ca}^{2+}$ signalling results from the entry of $\mathrm{Ca}^{2+}$ from the extracellular space (ECS) through ionotropic receptors (iR), voltage-gated channels (VGC) or store-operated channels (SOC). The intracellular source of $\mathrm{Ca}^{2+}$ is available from the endoplasmic reticulum (ER) intracellular stores that possess ryanodine and $\mathrm{IP}_{3}$ receptors (RyR and $\left.I P_{3} R\right)$. $I P_{3} R$ can be stimulated via activation of metabotropic receptors $(m R)$. Modified from ${ }^{[113]}$.

ER membrane also caries intracellular $\mathrm{Ca}^{2+}$ channels (the $\mathrm{Ca}^{2+}$ gated $\mathrm{Ca}^{2+}$ channels also known as ryanodine receptors and inositol $(1,4,5)$-trisphosphate $\left(\mathrm{IP}_{3}\right)$-gated $\mathrm{Ca}^{2+}$ channels or $\mathrm{IP}_{3}$ receptors), which, upon physiological stimulation, produce $\mathrm{Ca}^{2+}$ release $^{[49]}$ (Figure 3). Depleted stores are replenished by SERCA pumps from cytosol, while the ultimate source for this ion is the extracellular space and store-operated $\mathrm{Ca}^{2+}$ entry (SOCE) to cytoplasm (Figure 3); molecularly SOCE channels in astrocytes most likely belong to the family of transient receptor potential channels ${ }^{[50]}$. In addition to SOCE, $\mathrm{Ca}^{2+}$ entry across the plasma membrane involves a variety of other channels and/or receptors permeable to $\mathrm{Ca}^{2+[33,36]}$ (Figure 3). Additionally, mitochondria act as a source/sink of cytosolic $\mathrm{Ca}^{2+[51]}$. Both SERCA pumps and intracellular $\mathrm{Ca}^{2+}$ channels are subject to several feedback regulation cascades by cytosolic and intra-ER $\mathrm{Ca}^{2+[52]}$, which together with internal continuity of the ER lumen ${ }^{[53,54]}$ allow the development of propagating wave of channels opening following local stimulation. This propagating wave of activation of $\mathrm{ER} \mathrm{Ca}^{2+}$ channels forms glial excitability and underlie long-range signalling in glial syncytia manifested by propagating $\mathrm{Ca}^{2+}$ waves ${ }^{[5]]}$.

\section{Astrocytes release gliotransmitters}

Gliotransmitter is a chemical released from glial cells classified based on a working set of criteria: (i) synthesis by and/ or storage in glia; (ii) regulated release triggered by physiological and/or pathological stimuli; (iii) activation of rapid (milliseconds to seconds) responses in neighbouring cells; (iv) a role in (patho)physiological processes ${ }^{[56]}$. Since the first demonstration of the release of GABA from glial cells in superior cervical ganglia ${ }^{[57]}$ and taurine from primary cultured astrocytes $^{[58]}$, there has been an ongoing mission for determining and understanding of mechanisms and conditions that underlie gliotransmitter release. Generally, gliotransmitters can be released from astrocytes by several different mechanisms ${ }^{[56]}$ : (i) through channels like anion channel opening induced by cell swelling, release through unpaired connexons, hemichannels, on the cell surface and ionotropic purinergic receptors; (ii) through transporters such as reversal of uptake by plasma membrane excitatory amino acid transporters, exchange via the cystine-glutamate antiporter or organic anion transporters; (iii) through $\mathrm{Ca}^{2+}$-dependent exocytosis. Arbitrary, gliotransmitters can be divided into two general groups: (i) amino acids and their derivatives, such as glutamate, aspartate, homeocysteic acid, D-serine, GABA and taurine; (ii) nucleotides and their derivatives, like ATP, uridine $5^{\prime}$-triphosphate (UTP), adenosine and uridine diphosphate-glucose (UDP-glucose). We briefly outline mechanisms and conditions underlying the release of the gliotransmitter glutamate in chronological order of their discoveries (Figure 4).

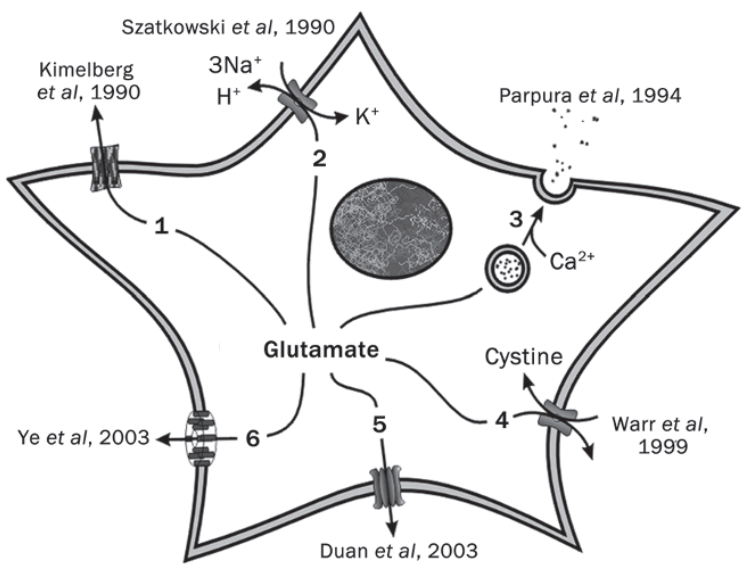

Figure 4. Glutamate release mechanisms in astrocytes. The six known mechanisms in are listed in the order of their discoveries along with original references: 1) swelling-induced opening of volume-regulated anion channels ${ }^{[59]}$; 2) reverse operation of excitatory amino acid transporters ${ }^{[60]}$; 3) $\mathrm{Ca}^{2+}$-dependent exocytosis ${ }^{[61]}$; 4) the cystine-glutamate exchanger ${ }^{[67]}$; 5) connexon hemichannels ${ }^{[69]}$; and 6) the $\mathrm{P} 2 \mathrm{X}_{7}$ receptor $^{[70]}$. Modified from $^{[113]}$.

\section{Swelling/anion channels}

Under hypo-osmotic conditions, such as those occurring during ischemia, most cells experience swelling and can compensate for this volume increase by opening volume-regulated anion channels. These channels are permeable to inorganic and small organic anions, including the amino acids taurine, aspartate and glutamate, all of which have been demonstrated to be released from astrocytes stimulated with hypoosmotic media to induce swelling ${ }^{[59]}$ (Figure 4, mechanism 1).

\section{Reverse operation of glutamate transporters}

An important function of astrocytes is continuous control of extracellular glutamate concentration that as accomplished through the use of the plasma membrane excitatory amino acid transporters (see below). Normally, concentration gradients favour the transport of glutamate into astrocytes. During extreme situations, such as ischemia or metabolic blockade, 
electro-chemical gradients can favour transporters to operate in reverse mode resulting in release of glutamate out of astrocytes $^{[60]}$ (Figure 4, mechanism 2).

\section{$\mathrm{Ca}^{2+}$-dependent exocytosis}

Regulated exocytosis is a process whereby the fusion of vesicular and plasma membranes result in the release of chemical transmitters which are then used for communication between various cells. It is an evolutionary trait of eukaryotic cells, with the majority of $\sim 200$ cell types present in the human body performing it. Indeed, it has been demonstrated that astrocytes can release glutamate in $\mathrm{Ca}^{2+}$-dependent manner ${ }^{[61]}$ (Figure 4, mechanism 3). Astrocytic secretory machinery includes the presence of vesicular structures as well as various endo/ exocytotic proteins ${ }^{[62]}$. Addition of vesicular membranes to the plasma membrane can be recorded as an increased cell capacitance with concomitant occurrence of glutamate release ${ }^{[63]}$. The cytosolic $\mathrm{Ca}^{2+}$ concentrations necessary and sufficient for glutamate release are likely to occur physiologically ${ }^{[56]}$. Some of the functional consequences of vesicular release from astrocytes are evident in the modulation of spontaneous and evoked synaptic transmission as well as synaptic plasticity ${ }^{[56]}$. There is also evidence that exocytotic release of ATP from astrocytes $^{[64]}$, that extracellularly converts to adenosine, plays a role in sleep ${ }^{[65]}$.

\section{Cystine-glutamate exchanger}

Cystine uptake in astrocytes is important for the production of the antioxidant, glutathione. It can occur via two known systems $\left(\mathrm{X}_{\mathrm{AG}^{-}}\right.$and $\left.\mathrm{x}_{\mathrm{c}^{-}}\right)$located on the plasma membrane. The majority of exchangers in the brain are localised in glial cells ${ }^{[66]}$. The $x_{c}$-system, which functions by importing cystine in exchange for glutamate, provides a pathway for glutamate release from astrocytes ${ }^{[67]}$ (Figure 4 , mechanism 4). This glutamate release was associated with the modulation of synaptic transmission and the expression of animal behaviour related to addiction ${ }^{[56]}$.

\section{Connexons}

Gap junction channels are pores formed by the joining of two connexons ("hemichannels") each on juxtaposing plasma membranes of adjacent cells. Unpaired connexons have been discovered to be able to act as functional hemichannels, capable of opening to the external space ${ }^{[68]}$. Their opening can provide a mechanism whereby transmitters, such as glutamate, diffuse out of astrocytes ${ }^{[56,69]}$ (Figure 4, mechanism 5). Such release of glutamate through hemichannels occurs under conditions of low extracellular divalent cations, which could occur during pathological conditions with altered divalent cations, like ischemia.

\section{$P 2 X_{7}$ receptors}

As alluded to earlier, $\mathrm{P} 2 \mathrm{X}_{7}$ expression in astrocytes is probably relevant for pathology in the brain, perhaps in ischemia. $P 2 X_{7}$ receptors are ATP-gated pore-forming ion channels that show amplified responses in low external divalent cation solution (same conditions as for connexon opening) and may provide another pathway for glutamate release from astrocytes ${ }^{[56,70]}$ (Figure 4, mechanism 6).

\section{Astrocytes control brain homeostasis}

Astrocytes are the main cellular element of extracellular homeostasis in the central nervous system. Numerous transport systems expressed in astroglial membranes provide the control over the concentrations of ions, neurotransmitters, neuromodulators, metabolites and other active molecules in the interstitium.

\section{Ion and water homeostasis}

Astroglia has the central role in regulation of extracellular $\mathrm{K}^{+}$. Astrocytes remove the excess of extracellular $\mathrm{K}^{+}$via local $\mathrm{K}^{+}$ uptake (accomplished by inward rectifier $\mathrm{K}^{+}$channels) and $\mathrm{K}^{+}$ spatial buffering ${ }^{[71,72]}$ The spatial $\mathrm{K}^{+}$buffering redistributes $\mathrm{K}^{+}$ from the areas with elevated $\left[\mathrm{K}^{+}\right]_{\mathrm{o}}$ to the regions with low $\left[\mathrm{K}^{+}\right]_{\mathrm{o}}$ and may occur either in the single glial cells $\left(\mathrm{K}^{+}\right.$siphoning in retinal Müller cells ${ }^{[73]}$ ) or within the glial syncytia. In addition astrocytes express aquaporin channels that are primarily responsible for regulation of brain water homeostasis ${ }^{[74]}$.

\section{Neurotransmitter homeostasis}

Astrocytes are responsible for extracellular homeostasis and turnover of various neurotransmitters. In particular astrocytes are central for glutamatergic neurotransmission because they provide for de novo glutamate synthesis, remove glutamate from the extracellular space and sustain the glutamateglutamine shuttle $\mathrm{e}^{[11,75]}$. Astrocytes specifically express EAAT1/GLAST and EAAT2/GLT-1 glutamate transporters that accomplish the bulk of glutamate uptake ${ }^{[76]}$. Recent experiments in acute slices indicate that ambient extracellular concentration of glutamate might be as low as about $25 \mathrm{nmol} / \mathrm{L}$ due to the activity of these transporters ${ }^{[7]}$. Glutamate transporters utilise the energy of the transmembrane $\mathrm{Na}^{+}$gradient co-transporting glutamate with $\mathrm{Na}^{+}, \mathrm{H}^{+}$, and $\mathrm{K}^{+}$. Activation of glutamate transporter leads to a substantial cytosolic $\mathrm{Na}^{+}$ accumulation that is counterbalanced by $\mathrm{Na}^{+}$efflux through $\mathrm{Na}^{+} / \mathrm{Ca}^{2+}$ exchanger working in the reverse mode ${ }^{[78,79]}$.

Glutamate, accumulated by astrocytes is enzymatically converted into glutamine by the astrocytic-specific glutamine synthetase; this glutamine then transported to neurones (glutamate-glutamine shuttle) where it provides the source of glutamate for subsequent accumulation into the exocytotic vesicles ${ }^{[11]}$.

\section{Control of local blood flow and metabolic support}

By dividing the grey matter into astroglial territories, astrocytes form neurovascular unit that integrate neural circuitry with local blood flow and metabolic support. The astrocyte couples the brain parenchyma and local vasculature by virtue of perivascular process and the endfeet. Increased neuronal activity triggers $\mathrm{Ca}^{2+}$ signals in the astrocyte, which, in turn, stimulate release of vasoactive agents that regulate the local blood flow ${ }^{[80-82]}$. Astrocytes also provide local metabolic sup- 
port of active neurones through the glucose-lactate shuttle, the activity of which is controlled by increases in cytosolic $\mathrm{Na}^{+}$ concentration ${ }^{[83]}$.

\section{Astrocytes in neuropathology}

Astrocytes being primary homeostatic cells of the central nervous system are fundamental for the development of all types of neurological diseases. In addition, astrocytes are in a possession of evolutionary conserved defensive programme known as reactive astrogliosis that very much defines the pathophysiological potential of astroglia. Astroglial homeostatic systems exert control over homeostatic imbalances induced by insulting the CNS. The astrogliosis, triggered in response to brain lesions of various aetiology ${ }^{[84,85]}$ is essential for limiting the area of damage (by scar formation through anisomorphic astrogliosis) and for the post-insult remodelling and recovery of neural function (by isomorphic astrogliosis). The astroglial homeostatic cascades however can be deleterious, when, upon excessive stress/damage of the nervous tissue, they may aggravate damage to the nervous system. Severe insults may compromise astroglial energetics and ion homeostasis, which in turn can trigger glutamate/ATP release (through reversed transporters or large-conductance plasmalemmal channels), release of $\mathrm{K}^{+}$ions that increase neuronal excitotoxicity, release of reactive oxygen species, pro-inflammatory factors and other neurotoxic agents ${ }^{[86-88]}$.

\section{Astrocytes in acute ischemia}

The ischemic infarction that occurs as a consequence of compromised blood flow triggers a specific lesion to the brain parenchyma. In the core of the infarction the cells undergo necrotic death, whereas the surrounding zone of ischemic penumbra still contains viable cells. The spread of the infarction through the penumbra determines the neurological outcome. The survival of cells in the penumbra very much depends on the preserved homeostatic capacity of astroglia. At the same time astroglial syncytia may represent a substrate of death signal propagation; these death signals occurring in the form of spreading waves of astroglial release of glutamate or ATP, developing of brain edema and compromised $\mathrm{K}^{+}$buffering $^{[87,89]}$.

\section{Astrocytes in epilepsy}

Epileptic brain tissue is characterised by profound astrogliotic reaction with astrocytes undergoing morphological and functional changes ${ }^{[90]}$. Focal seizures are associated with astroglial $\mathrm{Ca}^{2+}$ signalling ${ }^{[91]}$ and abnormal glutamate release from astrocytes can be also instrumental in inducing epileptiform seizures. The role of glutamate release from astrocytes in synchronous discharges triggering epileptiform seizures has been proposed $^{[92]}$. Finally compromised astroglial glutamate uptake also may contribute to epileptiform activity ${ }^{[33]}$.

\section{Astrocytes in hepatic encephalopathy (HE)}

$\mathrm{HE}$ is a potentially-reversible neuropsychiatric abnormality in the setting of both acute and chronic liver failure and it is pri- marily a disorder of astrocytes ${ }^{[94]}$. HE in chronic liver failure is characterized by the presence of "Alzheimer type II" astrocytes, which display morphological abnormalities. Neuronal cell death can be observed in the end-stage of liver failure and it is thought to be associated with the astrocytic dysfunction. The level of expression of several classes of astroglial proteins, including glutamine synthetase and EAATs, has been identified as potential etiological sites for this disorder ${ }^{[94]}$. However, discoveries of the presence of vesicular glutamate transporters $^{[95]}$ and NMDA receptors ${ }^{[37]}$ in astrocytes, especially when glutamate-mediated bidirectional neurone-astrocyte signalling is considered, may require reinterpretation of the course and treatment of HE.

\section{Astrocytes in other psychiatric disorders}

Astroglial cells are also involved in pathological developments in various psychiatric disorders. For example the density of astrocytes was decreased in patients suffering from depression $^{[96]}$. Astroglial cells may also be responsible for abnormal glutamate homeostasis which recently is considered as one of the leading pathological mechanisms of schizophrenia ${ }^{[97]}$.

\section{Astroglia in neurodegenerative diseases}

The pathological potential of astroglia in neurodegeneration began to be recognised only very recently. Furthermore it becomes apparent that several types of neurodegenerative diseases are associated astroglial atrophy. Conceptually degeneration of astrocytes may determine early cognitive deficits in neurodegeneration because reduced astroglial support can affect synaptic strength and lead to synaptic loss.

\section{Astrocytes in Alexander disease}

Alexander disease is the first discovered example of a primary astrogliopathy ${ }^{[98]}$. This disease is a fatal neurodegenerative disease mostly affecting infants and children, causing developmental delay and changes in physical characteristics. Here a defect in astrocytes as a consequence of mutation of the gene encoding for the intermediate filament protein GFAP results in this human disorder. Although the primary target of the GFAP mutations is the astrocyte, the clinical consequences are far more reaching affecting also oligodendrocytes and neurones. At present it is not clear how mutation(s) in GFAP can trigger this devastating disease, but certainly further understanding of the disease mechanisms will aide the development of much needed therapeutics.

\section{Astrocytes in amyotrophic lateral sclerosis (ALS)}

Neuroglial reactions play important role in ALS pathology. Prominent astroglial degeneration and atrophy was found in the animal model of Amyotrophic lateral sclerosis (the transgenic mice expressing $\mathrm{h}$ (uman)SOD ${ }^{\mathrm{G} 93 \mathrm{~A}}$ mutant). The atrophy if astrocytes in this model preceded both neuronal death and the appearance of clinical symptoms ${ }^{[99,100]}$. Reduced support of dopaminergic neurones by astroglial cells may contribute to selective cell death in Parkinson disease ${ }^{[86]}$. Astroglial degeneration was also observed in various forms of fronto-tempo- 
ral, thalamic and immunodeficiency virus-1 (HIV-1) associated dementia ${ }^{[101-103]}$.

\section{Astroglia in Alzheimer's disease}

Alzheimer's disease (AD) is one of the most feared among other neurodegenerative diseases because of stealth onset, relatively rapid and malignant progression which effectively degrades the human being to a position of a brainless beast. It is generally accepted that AD progression is associated with the parenchymal deposition of beta amyloid $(A \beta)$ in the form of senile/neuritic plaques, formation of neurofibrillary tangles (NFT), synaptic and neuronal loss. The pathological relevance of neuroglia for AD progression was realised by Alois Alzheimer himself after he discovered the glial cells being an integrative part of senile plaques ${ }^{[104]}$.

Reactive astrogliosis is the most commonly seen modification of astroglia in the post-mortem human tissues and in the brains of various AD animal models ${ }^{[105,106]}$. Incidentally, the depth of astrogliosis correlates directly with the cognitive decline but not with the $\beta$-amyloid load ${ }^{[107]}$.

Reactive astrogliosis in AD is initiated by many factors, which include signalling from damaged cells as well as extracellular deposition of $A \beta$. The exposure of astrocytes to $A \beta$ also results in an increased gap-junctional coupling in neocortical regions and an increased expression of AMPA/kainate glutamate receptors and glutamate transporters ${ }^{[108]}$. The astroglial expression of GLAST- and GLT-1 glutamate transporters was however inhibited in $A \beta$-overexpressing transgenic mice $^{[109]}$

Recent experiments, however, found another astroglial reaction at the early stages of family $\mathrm{AD}$. In triple-transgenic mice (3xTg-AD; harbouring the mutant genes for amyloid precursor protein $\left(\mathrm{APP}_{\mathrm{Swe}}\right)$, presenilin $1 \mathrm{PS}_{\mathrm{M} 146 \mathrm{~V}}$ and tau $\left.\mathrm{P}_{\mathrm{P} 01 \mathrm{~L}}{ }^{[109]}\right)$ a decrease in expression of GFAP and reduced morphological presence of astrocytes was found ${ }^{[106,110]}$. Early atrophic changes in astrocytes may be pathologically relevant as reduced astroglial coverage may lead to synaptic dysfunction and synaptic loss, both processes being prominent at the early phases of the AD. In addition astroglial atrophy may affect a vide range of brain homeostatic processes. Thus astropathology can represent a mechanism for early cognitive decline in $\mathrm{AD}$ and probably in other types of senile dementia.

\section{Conclusions}

Recent progress in glial neurobiology challenged the neurocentric views on the brain function. The glial cells, which underwent evolutionary explosion in the process of formation of the human brain, assume the most important functions of controlling neural cells development, promoting synaptogenesis, maintaining synaptic transmission and providing for all aspects of nervous system homeostasis. Furthermore, neuroglia represents the brain defence system and failure of glial function results in development many (if not all) of neurological diseases. The glial cells are also involved in various signalling processes, although whether neuroglia is directly responsible for higher brain functions remains the most challenging question of modern neuroscience.

\section{Acknowledgements}

Authors research was supported by Alzheimer's Research Trust (UK) Programme Grant (ART/PG2004A/1) to AV; by National Institute of Health (NIH) grant to VP (R01 MH 069791); by National Science Foundation (CBET 0943343) grant to VP, by the Grant Agency of the Czech Republic (GACR 305/08/1381 and GACR 305/08/1384) to AV.

\section{References}

1 Virchow R. Die Cellularpathologie in ihrer Begründung auf physiologische and pathologische Gewebelehre. Zwanzig Vorlesungen gehalten während der Monate Februar, März und April 1858 im pathologischen Institut zu Berlin. First edition ed. Berlin: August Hirschwald; 1858.

2 Kettenmann H, Verkhratsky A. Neuroglia: the 150 years after. Trends Neurosci 2008; 31: 653-9.

3 Verkhratsky A. Patching the glia reveals the functional organisation of the brain. Pflugers Arch 2006; 453: 411-20.

4 Lenhossek Mv. Zur Kenntnis der Neuroglia des menschlichen Ruckenmarkes. Verh Anat Ges 1891; 5: 193-221.

5 Andriezen WL. The neuroglia elements of the brain. Br Med J 1893; 2: $227-30$

6 Kölliker A. Handbuch der Gewebelehre des Menschen Leipzig Wilhelm Engelmann; 1889.

7 Del Río-Hortega P. El tercer elemento de los centros nerviosos. I. La microglia en estado normal. II. Intervencíon de la microglia en los procesos patológicos. III. Naturaleza probable de la microglia. Bol Soc Esp Biol 1919; 9: 69-120.

8 Del Río-Hortega P. Estudios sobre la neuroglia. La glia de escasas radiaciones oligodendroglia. Bol Soc Esp Biol 1921; 21: 64-92.

9 Del Río-Hortega P. Microglia. In: Penfield W editor. Cytology and celIular pathology of the nervous system. New York: Hoeber; 1932. p 482-534.

10 Retzius G. Die neuroglia des Gehirns beim Menschen und bei Saeugethieren. In: Biologische Untersuchungen, vol 6 Jena, Stockholm: Gustav Fischer, 1894, p 1-28.

11 Verkhratsky A, Butt A. Glial Neurobiology. A textbook. Chichester: John Wiley \& Sons; 2007.

12 Bushong EA, Martone ME, Ellisman MH. Maturation of astrocyte morphology and the establishment of astrocyte domains during postnatal hippocampal development. Int J Dev Neurosci 2004; 22: 73-86.

13 Bushong EA, Martone ME, Jones YZ, Ellisman MH. Protoplasmic astrocytes in CA1 stratum radiatum occupy separate anatomical domains. J Neurosci 2002; 22: 183-92.

14 Nedergaard M, Ransom B, Goldman SA. New roles for astrocytes: redefining the functional architecture of the brain. Trends Neurosci 2003; 26: 523-30.

15 Oberheim NA, Takano T, Han X, He W, Lin JH, Wang F, et al. Uniquely hominid features of adult human astrocytes. J Neurosci 2009; 29: 3276-87.

16 Ogata K, Kosaka T. Structural and quantitative analysis of astrocytes in the mouse hippocampus. Neuroscience 2002; 113: 221-33.

17 Halassa MM, Fellin T, Takano H, Dong JH, Haydon PG. Synaptic islands defined by the territory of a single astrocyte. J Neurosci 2007; 27: 6473-77.

18 Giaume C, Venance L. Intercellular calcium signaling and gap junctional communication in astrocytes. Glia 1998; 24: 50-64. 
19 Giaume C, Maravall M, Welker E, Bonvento G. The barrel cortex as a model to study dynamic neuroglial interaction. Neuroscientist 2009; 15: 351-66.

20 Wallraff A, Odermatt B, Willecke K, Steinhauser C. Distinct types of astroglial cells in the hippocampus differ in gap junction coupling. Glia 2004; 48: 36-43.

21 Araque A, Parpura V, Sanzgiri RP, Haydon PG. Tripartite synapses: glia, the unacknowledged partner. Trends Neurosci 1999; 22: 20815.

22 Perea G, Araque A. Astrocytes potentiate transmitter release at single hippocampal synapses. Science 2007; 317: 1083-6.

23 Ventura R, Harris KM. Three-dimensional relationships between hippocampal synapses and astrocytes. J Neurosci 1999; 19: 6897906.

24 Hatton GI. Glial-neuronal interactions in the mammalian brain. Adv Physiol Educ 2002; 26: 225-37.

25 Mudrick-Donnon LA, Williams PJ, Pittman QJ, MacVicar BA. Postsynaptic potentials mediated by GABA and dopamine evoked in stellate glial cells of the pituitary pars intermedia. J Neurosci 1993; 13: 4660-8.

26 Milner TA, Kurucz OS, Veznedaroglu E, Pierce JP. Septohippocampal neurons in the rat septal complex have substantial glial coverage and receive direct contacts from noradrenaline terminals. Brain Res 1995; 670: 121-36.

27 Matsui K, Jahr CE, Rubio ME. High-concentration rapid transients of glutamate mediate neural-glial communication via ectopic release. J Neurosci 2005; 25: 7538-47.

28 Lin SC, Bergles DE. Synaptic signaling between GABAergic interneurons and oligodendrocyte precursor cells in the hippocampus. Nat Neurosci 2004; 7: 24-32.

29 Jabs R, Pivneva T, Huttmann K, Wyczynski A, Nolte C, Kettenmann H, et al. Synaptic transmission onto hippocampal glial cells with hGFAP promoter activity. J Cell Sci 2005; 118: 3791-803.

30 Bowman CL, Kimelberg HK. Excitatory amino acids directly depolarize rat brain astrocytes in primary culture. Nature 1984; 311: 656-9.

31 Kettenmann H, Backus KH, Schachner M. Aspartate, glutamate and gamma-aminobutyric acid depolarize cultured astrocytes. Neurosci Lett 1984; 52: 25-9.

32 Steinhäuser C, Gallo V. News on glutamate receptors in glial cells. Trends Neurosci 1996; 19: 339-45.

33 Verkhratsky A, Steinhauser C. Ion channels in glial cells. Brain Res Brain Res Rev 2000; 32: 380-412.

34 Kirischuk S, Moller T, Voitenko N, Kettenmann H, Verkhratsky A. ATPinduced cytoplasmic calcium mobilization in Bergmann glial cells. J Neurosci 1995; 15: 7861-71.

35 Kirischuk S, Tuschick S, Verkhratsky A, Kettenmann H. Calcium signalling in mouse Bergmann glial cells mediated by $\alpha_{1}$-adrenoreceptors and $H_{1}$ histamine receptors. Eur J Neurosci 1996; 8: 1198-208.

36 Verkhratsky A, Orkand RK, Kettenmann H. Glial calcium: homeostasis and signaling function. Physiol Rev 1998; 78: 99-141.

37 Lalo U, Pankratov Y, Kirchhoff F, North RA, Verkhratsky A. NMDA receptors mediate neuron-to-glia signaling in mouse cortical astrocytes. J Neurosci 2006; 26: 2673-83.

38 Verkhratsky A, Kirchhoff F. NMDA Receptors in Glia. Neuroscientist 2007; 13: 28-37.

39 Verkhratsky A, Krishtal OA, Burnstock G. Purinoceptors on neuroglia. Mol Neurobiol 2009; 39: 190-208.

40 Burnstock G, Verkhratsky A. Evolutionary origins of the purinergic signalling system. Acta Physiol (Oxf) 2009; 195: 415-47.
41 Burnstock G, Fredholm BB, North RA, Verkhratsky A. The birth and postnatal development of purinergic signalling. Acta Physiol (Oxf) 2010; 199: 93-147.

42 Lalo U, Pankratov Y, Wichert SP, Rossner MJ, North RA, Kirchhoff F, et al. P2 $X_{1}$ and $P 2 X_{5}$ subunits form the functional $P 2 X$ receptor in mouse cortical astrocytes. J Neurosci 2008; 28: 5473-80.

43 Fellin T, Pozzan T, Carmignoto G. Purinergic receptors mediate two distinct glutamate release pathways in hippocampal astrocytes. J Biol Chem 2006; 281: 4274-84.

44 Sperlagh B, Vizi ES, Wirkner K, Illes P. P2X 7 receptors in the nervous system. Prog Neurobiol 2006; 78: 327-46.

45 Berridge MJ. The endoplasmic reticulum: a multifunctional signaling organelle. Cell Calcium 2002; 32: 235-49.

46 Verkhratsky A, Petersen $\mathrm{OH}$. The endoplasmic reticulum as an integrating signalling organelle: from neuronal signalling to neuronal death. Eur J Pharmacol 2002; 447: 141-54.

47 Solovyova N, Verkhratsky A. Monitoring of free calcium in the neuronal endoplasmic reticulum: an overview of modern approaches. J Neurosci Methods 2002; 122: 1-12.

48 Solovyova N, Veselovsky N, Toescu EC, Verkhratsky A. Ca ${ }^{2+}$ dynamics in the lumen of the endoplasmic reticulum in sensory neurons: direct visualization of $\mathrm{Ca}^{2+}$-induced $\mathrm{Ca}^{2+}$ release triggered by physiological $\mathrm{Ca}^{2+}$ entry. EMBO J 2002; 21: 622-30.

49 Verkhratsky A. Physiology and pathophysiology of the calcium store in the endoplasmic reticulum of neurons. Physiol Rev 2005; 85 : 201-79.

50 Malarkey EB, Ni Y, Parpura V. $\mathrm{Ca}^{2+}$ entry through TRPC1 channels contributes to intracellular $\mathrm{Ca}^{2+}$ dynamics and consequent glutamate release from rat astrocytes. Glia 2008; 56: 821-35.

51 Reyes RC, Parpura V. Mitochondria modulate $\mathrm{Ca}^{2+}$-dependent glutamate release from rat cortical astrocytes. J Neurosci 2008; 28 : 9682-91.

52 Burdakov D, Petersen $\mathrm{OH}$, Verkhratsky A. Intraluminal calcium as a primary regulator of endoplasmic reticulum function. Cell Calcium 2005; 38: 303-10.

53 Petersen $\mathrm{OH}$, Verkhratsky A. Endoplasmic reticulum calcium tunnels integrate signalling in polarised cells. Cell Calcium 2007; 42: 373-8.

54 Solovyova N, Verkhratsky A. Neuronal endoplasmic reticulum acts as a single functional $\mathrm{Ca}^{2+}$ store shared by ryanodine and inositol-1,4,5trisphosphate receptors as revealed by intra-ER $\left[\mathrm{Ca}^{2+}\right]$ recordings in single rat sensory neurones. Pflugers Arch 2003; 446: 447-54.

55 Cornell Bell AH, Finkbeiner SM, Cooper MS, Smith SJ. Glutamate induces calcium waves in cultured astrocytes: long-range glial signaling. Science 1990; 247: 470-73.

56 Parpura V, Zorec R. Gliotransmission: Exocytotic release from astrocytes. Brain Res Rev 2010; 63: 83-92.

57 Bowery NG, Brown DA, Collins GG, Galvan M, Marsh S, Yamini G. Indirect effects of amino-acids on sympathetic ganglion cells mediated through the release of gamma-aminobutyric acid from glial cells. $\mathrm{Br}$ J Pharmacol 1976; 57: 73-91.

58 Shain WG, Martin DL. Activation of beta-adrenergic receptors stimulates taurine release from glial cells. Cell Mol Neurobiol 1984; 4 : 191-6.

59 Kimelberg HK, Goderie SK, Higman S, Pang S, Waniewski RA. Swelling-induced release of glutamate, aspartate, and taurine from astrocyte cultures. J Neurosci 1990; 10: 1583-91.

60 Szatkowski M, Barbour B, Attwell D. Non-vesicular release of glutamate from glial cells by reversed electrogenic glutamate uptake. Nature 1990; 348: 443-6.

61 Parpura V, Basarsky TA, Liu F, Jeftinija K, Jeftinija S, Haydon PG. 
Glutamate-mediated astrocyte-neuron signalling. Nature 1994; 369 744-7.

62 Montana V, Malarkey EB, Verderio C, Matteoli M, Parpura V. Vesicular transmitter release from astrocytes. Glia 2006; 54: 700-15.

63 Zhang Q, Pangrsic T, Kreft M, Krzan M, Li N, Sul JY, et al. Fusionrelated release of glutamate from astrocytes. J Biol Chem 2004; 279: 12724-33.

64 Pangrsic T, Potokar M, Stenovec M, Kreft M, Fabbretti E, Nistri A, et al. Exocytotic release of ATP from cultured astrocytes. J Biol Chem 2007; 282: 28749-58.

Halassa MM, Florian C, Fellin T, Munoz JR, Lee SY, Abel T, et al. Astrocytic modulation of sleep homeostasis and cognitive consequences of sleep loss. Neuron 2009; 61: 213-9.

66 Pow DV. Visualising the activity of the cystine-glutamate antiporter in glial cells using antibodies to aminoadipic acid, a selectively transported substrate. Glia 2001; 34: 27-38.

67 Warr O, Takahashi M, Attwell D. Modulation of extracellular glutamate concentration in rat brain slices by cystine-glutamate exchange. J Physiol 1999; 514: 783-93.

68 Hofer A, Dermietzel R. Visualization and functional blocking of gap junction hemichannels (connexons) with antibodies against external loop domains in astrocytes. Glia 1998; 24: 141-54.

69 Ye ZC, Wyeth MS, Baltan-Tekkok S, Ransom BR. Functional hemichannels in astrocytes: a novel mechanism of glutamate release. J Neurosci 2003; 23: 3588-96.

70 Duan S, Anderson CM, Keung EC, Chen Y, Chen Y, Swanson RA. P2X receptor-mediated release of excitatory amino acids from astrocytes. J Neurosci 2003; 23: 1320-8.

71 Kofuji P, Newman EA. Potassium buffering in the central nervous system. Neuroscience 2004; 129: 1045-56.

72 Newman EA. Glial cell regulation of extracellular potassium. In: Kettenmann H, Ransom B editors. Neuroglia. NY: Oxford University Press; 1995. p 717-31.

73 Newman EA, Frambach DA, Odette LL. Control of extracellular potassium levels by retinal glial cell $\mathrm{K}^{+}$siphoning. Science 1984; 225 : 1174-5.

74 Simard M, Nedergaard M. The neurobiology of glia in the context of water and ion homeostasis. Neuroscience 2004; 129: 877-96.

75 Swanson RA. Astrocyte neurotransmitter uptake. In: Kettenmann H, Ransom B editors. Neuroglia. Oxford: Oxford Univeristy Press; 2005. p 346-54.

76 Danbolt NC. Glutamate uptake. Progr Neurobiol 2001; 65: 1-105.

77 Herman MA, Jahr CE. Extracellular glutamate concentration in hippocampal slice. J Neurosci 2007; 27: 9736-41.

78 Kirischuk S, Kettenmann $\mathrm{H}$, Verkhratsky A. $\mathrm{Na}^{+} / \mathrm{Ca}^{2+}$ exchanger modulates kainate-triggered $\mathrm{Ca}^{2+}$ signaling in Bergmann glial cells in situ. FASEB J 1997; 11: 566-72.

79 Kirischuk S, Kettenmann H, Verkhratsky A. Membrane currents and cytoplasmic sodium transients generated by glutamate transport in Bergmann glial cells. Pflugers Arch 2007; 454: 245-52.

80 Metea MR, Newman EA. Glial cells dilate and constrict blood vessels: a mechanism of neurovascular coupling. J Neurosci 2006; 26 : 2862-70.

81 Zonta M, Angulo MC, Gobbo S, Rosengarten B, Hossmann KA, Poz zan T, et al. Neuron-to-astrocyte signaling is central to the dynamic control of brain microcirculation. Nat Neurosci 2003; 6: 43-50.

82 ladecola $\mathrm{C}$, Nedergaard M. Glial regulation of the cerebral microvasculature. Nat Neurosci 2007; 10: 1369-76.

83 Magistretti PJ. Neuron-glia metabolic coupling and plasticity. J Exp Biol 2006; 209: 2304-11.

84 Sofroniew MV. Molecular dissection of reactive astrogliosis and glial scar formation. Trends Neurosci 2009; 32: 638-47.

85 Sofroniew MV, Vinters HV. Astrocytes: biology and pathology. Acta Neuropathol 2010; 119: 7-35.

86 Heneka MT, Rodriguez JJ, Verkhratsky A. Neuroglia in neurodegeneration. Brain Res Rev 2010; 63: 189-211.

87 Nedergaard M, Rodriguez JJ, Verkhratsky A. Glial calcium and diseases of the nervous system. Cell Calcium 2010; 47: 140-9.

88 Nedergaard M, Dirnagl U. Role of glial cells in cerebral ischemia. Glia 2005; 50: 281-6.

89 Giaume C, Kirchhoff F, Matute C, Reichenbach A, Verkhratsky A. Glia: the fulcrum of brain diseases. Cell Death Differ 2007; 14: 1324-35.

90 Seifert G, Schilling K, Steinhauser C. Astrocyte dysfunction in neurological disorders: a molecular perspective. Nat Rev Neurosci 2006; 7: 194-206.

91 Gomez-Gonzalo M, Losi G, Chiavegato A, Zonta M, Cammarota M, Brondi $\mathrm{M}$, et al. An excitatory loop with astrocytes contributes to drive neurons to seizure threshold. PLoS Biol 2010; 8: e1000352.

92 Tian GF, Azmi H, Takano T, Xu Q, Peng W, Lin J, et al. An astrocytic basis of epilepsy. Nat Med 2005; 11: 973-81.

93 Tanaka K, Watase K, Manabe T, Yamada K, Watanabe M, Takahashi $\mathrm{K}$, et al. Epilepsy and exacerbation of brain injury in mice lacking the glutamate transporter GLT-1. Science 1997; 276: 1699-702.

94 Butterworth RF. Hepatic encephalopathy: A primary astrocytopathy. In: Parpura V, Haydon PG editors. Astrocytes in (patho)physiology of the nervous system. Boston (MA): Springer; 2009. p 673-92.

95 Montana V, Ni Y, Sunjara V, Hua X, Parpura V. Vesicular glutamate transporter-dependent glutamate release from astrocytes. J Neurosci 2004; 24: 2633-42.

96 Rajkowska G, Miguel-Hidalgo JJ, Wei J, Dilley G, Pittman SD, Meltzer $\mathrm{HY}$, et al. Morphometric evidence for neuronal and glial prefrontal cell pathology in major depression. Biol Psychiatry 1999; 45: 108598.

97 Tsai G, Coyle JT. Glutamatergic mechanisms in schizophrenia. Annu Rev Pharmacol Toxicol 2002; 42: 165-79.

98 Brenner M, Goldman JE, Quinlan RA, Messing A. Alexander disease: A genetic disorder of astrocytes. In: Parpura V, Haydon PG editors. Astrocytes in (patho)physiology of the nervous system. Boston (MA): Springer; 2009. p 591-648.

99 Rossi D, Brambilla L, Valori CF, Roncoroni C, Crugnola A, Yokota T, et al. Focal degeneration of astrocytes in amyotrophic lateral sclerosis. Cell Death Differ 2008; 15: 1691-700.

100 Rossi D, Volterra A. Astrocytic dysfunction: Insights on the role in neurodegeneration. Brain Res Bull 2009; 80: 224-32.

101 Broe M, Kril J, Halliday GM. Astrocytic degeneration relates to the severity of disease in frontotemporal dementia. Brain 2004; 127 : 2214-20.

102 Potts R, Leech RW. Thalamic dementia: an example of primary astroglial dystrophy of Seitelberger. Clin Neuropathol 2005; 24: 271-5.

103 Thompson KA, McArthur JC, Wesselingh SL. Correlation between neurological progression and astrocyte apoptosis in HIV-associated dementia. Ann Neurol 2001; 49: 745-52.

104 Alzheimer A. Beiträge zur Kenntnis der pathologischen Neuroglia und ihrer Beziehungen zu den Abbauvorgängen im Nervengewebe. In: NissI F, Alzheimer A editors. Histologische und Histopathologische Arbeiten über die Grosshirnrinde mit besonderer Berücksichtigung der pathologischen Anatomie der Geisteskrankheiten Jena: Verlag von Gustav Fischer; 1910. p 401-562.

105 Nagele RG, Wegiel J, Venkataraman V, Imaki H, Wang KC. Contribution of glial cells to the development of amyloid plaques in Alzheimer's disease. Neurobiol Aging 2004; 25: 663-74. 
106 Rodriguez JJ, Olabarria M, Chvatal A, Verkhratsky A. Astroglia in dementia and Alzheimer's disease. Cell Death Differ 2009; 16: 378-85.

107 Simpson JE, Ince PG, Lace G, Forster G, Shaw PJ, Matthews F, et al. Astrocyte phenotype in relation to Alzheimer-type pathology in the ageing brain. Neurobiol Aging 2010; 31: 578-90.

108 Peters O, Schipke CG, Philipps A, Haas B, Pannasch U, Wang LP, et al. Astrocyte function is modified by Alzheimer's disease-like pathology in aged mice. J Alzheimers Dis 2009; 18: 177-89.

109 Matos M, Augusto E, Oliveira CR, Agostinho P. Amyloid- $\beta$ peptide decreases glutamate uptake in cultured astrocytes: involvement of oxidative stress and mitogen-activated protein kinase cascades. Neuroscience 2008; 156: 898-910.
110 Olabarria M, Noristani HN, Verkhratsky A, Rodriguez JJ. Concomitant astroglial atrophy and astrogliosis in a triple transgenic animal model of Alzheimer's disease. Glia 2010; 58: 831-8.

111 Peters A, Palay SL, Webster Hd. The fine structure of the nervous system. 3rd ed. New York: Oxford Oxford University Press; 1991.

112 Bezzi P, Gundersen V, Galbete JL, Seifert G, Steinhauser C, Pilati E, et al. Astrocytes contain a vesicular compartment that is competent for regulated exocytosis of glutamate. Nat Neurosci 2004; 7: 613-20.

113 Malarkey EB, Parpura V. Glutamate release from astrocytes: impact on neuronal function. In: Häussinger D, Kircheis G, Schliess F editors. Hepatic encephalopathy and nitrogen metabolism. LondonHeidelberg: Springer; 2006. p 60-86. 